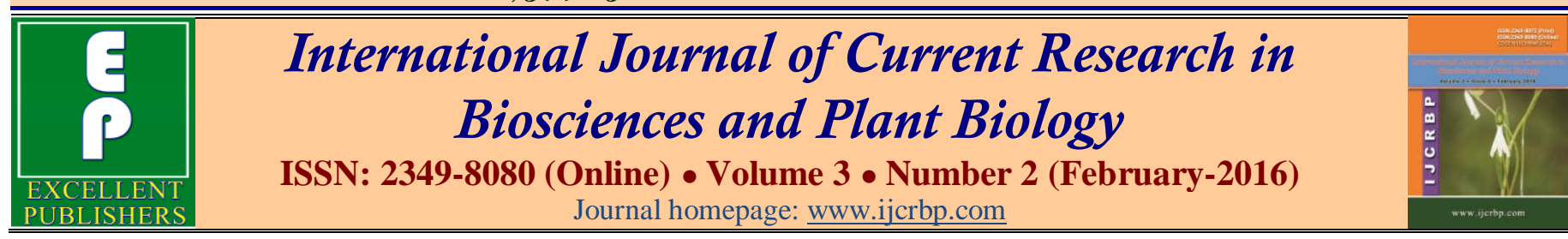

Case Report

doi: $\underline{\text { http://dx.doi.org/10.20546/ijcrbp.2016.302.008 }}$

\title{
Study on Mastitis in Dairy Cows at Wayanad District, Kerala, South India
}

\author{
M.D. Dinesh ${ }^{*}$, Ayona George ${ }^{1}$, Athira Vijayan¹, C.C. Divya1, Jyothi Sathyan¹, K.M. Susmitha, \\ Smitha Chacko', M.C. Vijisha ${ }^{1}$ and S. Meenatchisundaram ${ }^{2}$ \\ ${ }^{1}$ Department of Microbiology, Pazhassiraja College, Pulpally, Wayanad-673 579, Kerala, India \\ 2Department of Microbiology, Nehru Arts and Science College, Thirumalayampalayam, Coimbatore-641 105, Tamil Nadu, India
}

*Corresponding author.

\begin{abstract}
A bstract
The cow is one of the remarkable domestic animals in the world, adapted to live in arid and semi-arid conditions. In India, cow is inherently associated with the culture, religion and social life of the most of the communities. Udder is a productive organ of dairy animals; hence for better production it should be fit. Because of its anatomical position is subjected to outside influences and is level to both inflammatory and non inflammatory conditions. Mastitis has been and continues to be known as one of the major disease harms regarding the dairy industry. In the review article discuss the status of mastitis infections in Wayanad.
\end{abstract}

\section{Article Info}

Accepted: 21 January 2016

Available Online: 06 February 2016

Keywords

Dairy animals

Etiology

Mastitis

\section{Introduction}

Mastitis is a multietiological complex disease, which is defined as inflammation of parenchyma of mammary glands and is characterized by physical, chemical and usually bacteriological changes in milk and pathological changes in glandular tissues (Radostits et al., 2000). It is also one of the most costly diseases confronting the dairy farmer. Estimating economic losses resulting from mastitis becomes an extremely difficult task because of the many levels of infection and other factors.

Fortunately, the vast majority of mastitis cases is caused by a relatively small number of microorganisms that can be grouped into three categories: (1) contagious; (2) environmental and (3) other. Mastitis is caused by many gram positive and gram negative bacteria. Gram-negative bacteria that commonly cause bovine mastitis are classified as environmental pathogens include Escherichia coli, Klebsiella pneumoniae, Klebsiella oxytoca, Serratia species, Citrobacter species, Enterobacter aerogenes, Streptococcus uberis, Streptococcus bovis and
Streptococcus dysgalactiae. Contagious are caused by Staphylococcus aureus, Streptococcus agalactiae, Corynebacterium bovis and Mycoplasma species. The other organisms group consist of Coagulase-negative staphylococci (CNS), Serratia species, Pseudomonas aeruginosa, Nocardia asteroids, Prototheca species, Candida species (yeasts) and Arcanobacterium pyogenes (Corynebacterium pyogenes).

\section{Clinical signs}

The mastitis may be classified into subclinical and clinical mastitis. Subclinical mastitis is a form of mastitis in which there is no readily detectable change in the udder itself and no observable abnormality of the milk. Clinical mastitis indicates that there are visible changes in the udder, such as swelling, heat, redness, pain and disturbed functions, and or visible changes in the milk, such as clots (gargot) or watery secretions and systemic reactions in varying degrees. Clinical mastitis is further divided into peracute, acute, subacute and chronic mastitis (Uma et al., 2012). 


\section{Diagnosis}

Unlike the clinical mastitis, in sub clinical mastitis there is neither visual abnormalities in milk (like blood, clots, flakes etc) nor in mammary gland (like swelling, hotness, cracks etc). Therefore, knowledge of routine physical examination of udder and diagnostic screening tests for early detection of mastitis and proper treatment of affected animal is one of the paramount importance in order to minimized losses encountered due to sub clinical as well as clinical mastitis. Clinical mastitis is easily visible/diagnosed as udder swelling, pain and drastic decreased milk production even by farmers also. Clinical examinations include Physical examination of udder, Milk examination, Direct or cultural tests, Indirect Tests, Direct/Cultural test. Indirect test include Somatic cell count, California Mastitis Test, Strip cup test, Sodium lauryl sulphate test (SLS test), White side test (WST), Surf field mastitis test (Uma et al., 2012).

\section{International status}

Mastitis is the most prevalent production disease in dairy herds world-wide and is responsible for several production effects. Milk yield and composition can be affected by a more or less severe short-term depression and, in case of no cure, by a long-acting effect, and, sometimes, an overlapping effect to the next lactation. Summary values in the literature for losses of milk production were proposed at $375 \mathrm{~kg}$ for a clinical case $(5 \%$ at the lactation level) and at $0.5 \mathrm{~kg}$ per 2-fold increase of crude SCC of a cow. Due to the withdrawal period after treatment, composition changes in milk can almost be neglected in economic calculations. Lethality rate for clinical mastitis is very low on the average, while anticipated culling occurs more frequently after clinical and subclinical mastitis (relative risk between 1.5 and 5.0). The economics of mastitis needs to be addressed at the farm level and, per sector, depends on local and regional epidemological, managerial and economic conditions. To assess the direct economic impact of mastitis, costs (i.e. extra resource use) and losses (i.e. reduced revenues) have to be aggregated. To support decision making for udder health control, it is necessary to use a marginal approach, based on the comparison of the losses avoided and the additional costs of modified plans, compared to the existing one (Seegers et al., 2003).

Mastitis continues to be the most frequent and costly disease of dairy cattle. Financial losses due to mastitis occur for both subclinical and clinical stages of the disease. Losses caused by subclinical mastitis are well documented. Each doubling of SCC above 50,000cells $/ \mathrm{ml}$ results in a loss of $0.4 \mathrm{~kg}$ and $0.6 \mathrm{~kg}$ of milk per day in first lactation and older cows, respectively (Hortet and Seegers, 1998). Losses caused by clinical mastitis include discarded milk, transient reductions in milk yield and premature culling (Fetrow, 2000).

\section{Status of mastitis in dairy animals in India}

In India, Staphylococcus, Streptococcus and E. coli generally cause $90-95 \%$ of all infections of mammary gland (mastitis). The goal of every dairy farmer should be to minimize the number of organisms permitted to come into contact with the teats. In India, the teat dipping as a preventive measure is not regularly practiced by dairy farmers; hence, it is essential to educate the farmers regarding the risk factors of mastitis and also about teat dipping (Kavitha et al., 2009). Mastitis, on account of its causing serious wastage and undesirable milk quality, is emerging as a major challenge. Subclinical mastitis was found more important in India (varying from $10-50 \%$ in cows and 5-20\% in buffaloes) than clinical mastitis (110\%). The incidence was highest in Purebred Holsteins and Jerseys and lowest in local cattle and buffaloes. An investigation on 250 animals from periurban farms indicated that the monsoon season was more prone to subclinical mastitis than summer or winter, prevalence increased with higher lactation number and animals in 4th-5th month of lactation were found more susceptible $(59.49 \%)$, hind quarters were found more affected $(56.52 \%)$ than fore quarters $(43.47 \%)$. The factors like herd size, agro climatic conditions of the region, variations in sociocultural practices, milk marketing, literacy level of the animal owner, system of feeding, and management were found important affecting the incidence of subclinical mastitis. Comparison of efficacy of different diagnostic techniques for subclinical mastitis, such as modified California mastitis test (MCMT), bromo thymol blue (BTB), modified whiteside test, trypsin inhibition test, milk $\mathrm{pH}$, and electric conductivity indicated MCMT to be most sensitive $(95.16 \%)$ and specific $(98.02 \%)$ test. It was concluded that consideration of socioecological factors for mastitis control in periurban area would help to reduce the cost of mastitis control in clean milk production (Joshi et al., 2006).

\section{Status of mastitis status in Kerala}

The agricultural setting in Kerala is rather exceptional and distinct from many other States in India in terms of land use pattern and the cropping mould. The livestock sub sector has emerged as one of the key components of 
agricultural growth in developing countries in recent years. In Kerala, nearly 94 per cent of the livestock population is concentrated in rural areas, 80 per cent of the livestock farmers are marginal farmers and agricultural labourers. Women constitute 60 per cent of the workforce in this sector. Most of the cattle holdings are one cow farms. Nearly 65 per cent of the meat required is met from animals of neighbouring States. According to livestock census figures the cattle population in the State was 21.22 lakhs of which 17.35 lakhs were crossbred (i.e., $81.8 \%$ of the total cattle population).

Mixed farming combining crop husbandry with animal husbandry is the best strategy for maximization of income for small and marginal farmers who contribute bulk of the farming community in Kerala. The planned development of livestock sector can solve to a greater extent some of the basic and chronic problems of the state like low rate of growth and high incidence of unemployment, under employment, malnutrition and food deficit. As a result of the successful cattle development programmes undertaken in the state, Kerala could convert about 67 percentage of its cattle population into high yielding crossbred. The crossbred are having high production potential compared to the non-descript desi breeds and hence the value of livestock wealth has also increased. These changes have contributed to rapid increase in the production and consumption of milk. The growth in milk production has also contributed to an increase in the percentage share of income from dairy sector to the state domestic product from agriculture. (George and Nair, 1990). Though cross breeding helped in increasing the production potential of cattle, it decreased the disease resistance ability of the cattle making them vulnerable to many production diseases, causing considerable loss in the state's economy. In terms of economic loss mastitis is one of the most important disease in the diary sector (Blood and Radostits, 1989).

Estimates show that on the standard a district affected with mastitis results in a 30\% reduction in efficiency and an affect cow is estimated to loss $15 \%$ of its production (Blood and Radostits, 1989). In most countries surveys on the incidence of Mastitis irrespective of the cause shows comparable figures of about $40 \%$ morbidity among dairy cows. According to the Reports available in the Directorate of Animal Husbandry, Kerala shows that there were 90336 reported cases of mastitis in Kerala during 1998-'99. It accounts to about 5\% of female cattle population of Kerala. There can be at least a comparable number of non-reported cases of clinical Mastitis and much more number of non-reported sub clinical Mastitis cases during the same period.

\section{Mastitis status - Wayanad region}

Wayanad is a district in the God's on country state, India with headquarters at the town of Kalpetta. Wayanad district is in the southern tip of the Deccan Plateau. Part of the Western Ghats is in the district. In the centre of the district hills are lower in height while the northern area has high hills. The eastern area is flat and open. Wayanad is surrounded by large amount of dry and moist deciduous forest and harbour of species and traditional medicinal plants. Wayanad is $3.79 \%$ urbanised. Agriculture is the stronghold of the economy. Cattle farming are another major income earner for the people of Wayanad. Dairy husbandry is success more popular among farmers in Wayanad district. Milk production has increased in the past three years, and a number of farmers selected Dairy farming as their major income source.

Recent reports suggested that rising accessibility of land as well as the use of easily accusable raw materials as feeds like beer waste and oil cakes has helped in reducing the cost of production. Even with the current milk price, farmers are getting better income from Dairy farming. Mastitis is a disease complex of different etiology and different degrees of intensity along with variations in duration and residual effects (Schalm et al., 1971). Occurrence of mastitis, a potentially fatal mammary gland infection, is high in the middle of dairy cattle due to not disinfected cattle sheds including rude floor covering. Rising cost of manufacture, increasing dealing cost and decreasing output are the major issues raised by farmers in the Wayanad district. Many farmers fail to reach proper treatments in time or seek therapeutic care after a considerable hold-up because many farmers were relying on traditional practices to control diseases, it could not produce any positive results. According to the survey of Kerala Veterinary and Animal Sciences University (KVASU) suggested that scientific housing, feeding, dairy management and disease control measures can reduce the cost of production and can make dairying more profitable in the State.

According to the survey reports from District Veterinary and dis-husbandry Department, Kalpatta, Wayanad number of mastitis cases is reported in Kalpata in the year of 2015. The mastitis cases reported in Wayanad district hospitals from the period of June 2015 to December 2015 are listed below (Table 1 and Table 2). 
Table 1. The mastitis cases recorded in Wayand hospitals (June 2015 to December 2015).

\begin{tabular}{llllllll}
\hline Wayand District & June & July & August & September & October & November & December \\
& $\mathbf{2 0 1 5}$ & $\mathbf{2 0 1 5}$ & $\mathbf{2 0 1 5}$ & $\mathbf{2 0 1 5}$ & $\mathbf{2 0 1 5}$ & $\mathbf{2 0 1 5}$ & $\mathbf{2 0 1 5}$ \\
\hline Kalpetta & 131 & 132 & 106 & 144 & 155 & 140 & 148 \\
Manathavadi & 100 & 103 & 105 & 120 & 140 & 125 & 72 \\
Sulthan Bathery & 60 & 61 & 21 & 70 & 50 & 75 & 71 \\
Panamaram & 80 & 81 & 95 & 80 & $\mathbf{4 0 5}$ & $\mathbf{4 2 0}$ & $\mathbf{4 0 6}$ \\
Total & $\mathbf{3 7 1}$ & $\mathbf{3 7 7}$ & $\mathbf{3 2 7}$ & $\mathbf{4 1 4}$ & $\mathbf{4 0 5}$ & \\
\hline
\end{tabular}

Table 2. The mastitis cases treated in Wayanad hospitals.

\begin{tabular}{lll}
\hline Wayanad District & Cases treated in the year 2015 & Number of deaths reported \\
\hline Kalpetta & 1800 & Nil \\
Manathavadi & 1310 & Nil \\
Sulthan Bathery & 200 & Nil \\
Panamaram & 500 & NIL \\
Total & $\mathbf{3 8 1 0}$ & - \\
\hline
\end{tabular}

Source: District Veterinary and dis-husbandary Department- Kalpetta, Wayanad.

\section{Conclusion}

Mastitis treatment with antibiotics leads to the development of antibiotic resistant strains and consumer health problem. Clinical mastitis treatment protocols are based on treating the mastitic quarter to clear the infection and return the milk and quarter to normal. Broad spectrum antibiotics are used widely for the current therapies. The medicinal plants are in great demand in traditional system of medicine i.e. Ayurveda, Siddha and Unani Tibb as well as folklore prescriptions. The modern pharmaceutical industry also requires a large quantity of authentic plants for manufacture of drugs. Use of herbal medicine, sometimes also referred as 'Herbalism', is an ancient practice for healing.

\section{Conflict of interest statement}

Authors declare that they have no conflict of interest.

\section{References}

Blood, D. C., Radostits, O. M., 1989. Veterinary Medicine. W.B. Saunders Company, Philadelphia.

Fetrow, J., 2000. Mastitis: an economic consideration. In: Proceedings of the $29^{\text {th }}$ Annual Meeting of Natl. Mast. Coun., Atlanta, GA and Madison, WI. pp.3-47.
George, P.S., Nair, K.N., 1990. Livestock Economy of Kerala. Centre for Development Studies, Tiruvananthapuram.

Hortet, P., Seegers, H., 1998. Milk yield loss and related composition changes resulting from clinical mastitis in dairy cows: a review. Prev. Vet. Med. 37, 1-20.

Joshi, S., Gokhale, S., 2006. Status of mastitis as an emerging disease in periurban dairy farms in India. Ann. New York Acad. Sci. 1081, 74-83.

Kavitha, K.L., Rajesh, K., Suresh, K., Satheesh, K., Syamasundar, N., 2009. Buffalo mastitis- risk factors. Buffalo Bull. 28, 134-137.

Radostits, O.M., Gay, C.C., Blood, D.C., Hinchliff, K.W., 2000. Caudal vena caval thrombosis and embolic pneumonia in cattle (posterior vena caval thrombosis, PVCT). In: Veterinary Medicine. A Textbook of the Diseases of Cattle, Sheep, Pigs, Goats and Horses. $9^{\text {th }}$ Edn. W.B. Saunders, London. pp.451-452.

Schalm, O.W., Carroll, E.J., Jain, N.C., 1971. Bovine Mastitis. Lea and Febiger, Philadelphia.

Seegers, H., Fourichon, F., Beaudeau, F., 2003. Production effects related to mastitis and mastitis economics in dairy cattle herds. Vet. Res. 34(5), 475-491.

Uma, M.S., Dinesh, M.D., Anjali, V.M., Rechana, R., Meenatchisundaram, S., Shanmugam, V., 2012. Purification and characterization of chicken egg yolk antibodies (IgY) against mastitis causing Klebsiella pneumonia. Eur. J. Biol. Sci. 4(2), 35-39.

\section{How to cite this article:}

Dinesh, M.D., Ayona, G., Athira, V., Divya, C.C., Jyothi, S., Susmitha, K.M., Smitha, C., Vijisha, M.C., Meenatchisundaram, S., 2016. Study on mastitis in dairy cows at Wayanad District, Kerala, South India. Int. J. Curr. Res. Biosci. Plant Biol. 3(2), 65-68. doi: http://dx.doi.org/10.20546/ijcrbp.2016.302.008 